\title{
Advancing environmental sustainability through nature-based science tourism: The potential of universities
}

Juulia Räikkönen, University of Turku, Turku School of Economics \& Biodiversity Unit Henna Rouhiainen, University of Turku, Biodiversity Unit \& Department of Biology Miia Grénman, University of Turku, Turku School of Economics \& Biodiversity Unit Ilari E. Sääksjärvi, University of Turku, Biodiversity Unit

\section{Abstract}

This review examines the potential of universities to advance environmental sustainability through nature-based science tourism, in which scientists are actively involved in co-creating nature-based tourism experiences. We first justify the review by presenting the current changes facing academia, namely the pressure to increase societal effectiveness, science democratization, and environmental sustainability. Then, we define science tourism and address the role of science and scientists in nature-based tourism. Finally, we evaluate the potential of nature-based science tourism to affect tourists' environmental knowledge, attitudes and behavior. Based on previous literature, we suggest that universities and scientists, who have the knowledge about environmental sustainability, biodiversity crisis, and climate change, could have a more significant role in providing nature-based tourism experiences and shaping tourists' attitudes and behavior regarding environmental sustainability. In line with recent discussions on science dissemination, this requires not only providing scientific knowledge to large audiences but also active scientific engagement and interaction with tourists.

Keywords: nature-based tourism, environmental sustainability, environmental education, science tourism, scientific tourism

\section{Introduction}

The current review focuses on the potential of universities to advance environmental sustainability through nature-based science tourism. Universities play a critical role in advancing sustainable development by creating new knowledge through conducting scientific research, educating future leaders, and disseminating science to large audiences (e.g., Christie, Miller, 
Cooke, \& White, 2015). In a sense, universities have a moral obligation to act as exemplars in advancing sustainable development in the wider society (e.g., Scott \& Gough, 2007; Wright, 2004). Indeed, universities have often led the environmental movement (Weissman, 2012) and promoted sustainability in teaching, research, and campus operations through various international declarations (Christie et al., 2015). However, there is still room for improvement and a need for innovative policies that can advance both environmental sustainability and the societal effectiveness of universities.

As global tourism and leisure consumption continue to grow rapidly, it is important to discuss the negative implications that the tourism industry causes to natural and cultural environments. However, it is also essential to consider the possibilities that tourism can offer to sustainable development. Here, we focus on nature-based tourism, which refers to various tourism activities that enable tourists to get in touch with nature (Hall \& Williams, 2008). By science tourism, we mean tourism activities in which scientists are actively involved in co-creating tourism experiences (cf. Bourlon \& Torres, 2016).

Environmental issues, such as the biodiversity crisis, form the most critical challenges of the current era, threatening not only species and ecosystems but also the living conditions - and the entire existence - of humankind. Biodiversity is commonly understood as the number of species in a given region, even though biologically it refers to the sum of biotic variation within species and ecosystems (Gössling, 2018; Thompson \& Starzomski, 2007). Biodiversity is considered one of the most central components in the functioning of natural ecosystems, and thus it is also essential for human well-being. Biodiversity is constantly changing, but during the past centuries this change has been accelerated by human actions. The decline of biodiversity is exacerbated by global environmental change caused by changes in land and sea use, direct exploitation of organisms, climate change, pollution, and invasion of alien species (Diaz et al., 2019; Gössling, 2018).

One of the most widely accepted remedies for environmental change and the related social and cultural challenges is sustainable development. Although a highly contested concept, sustainable development is usually understood as a continuous change in society, aiming to secure opportunities for a good life for the current and future generations through the sustainable use of natural resources. Sustainable development traditionally consists of environmental, social, and economic dimensions, but nowadays cultural sustainability is also often included (Brundtland, Khalid, \& Agnelli, 1987; Dessein, Soini, Fairclough, \& Horlings, 2015; Leal Filho, 2000). Currently, however, emphasis is increasingly placed on the significance of large-scale transformative changes in societies and capitalist economic systems (Diaz et al., 2019).

There is an inherent contradiction between sustainability and development, which is often understood in economic terms, privileging economic discourses over the other dimensions. In the current paper, the focus is on environmental sustainability, which is often considered to form the basis of all sustainability, as human well-being is dependent on the environment (Brundtland et al., 1987; Hopwood, Mellor, \& O’Brien, 2005). Moreover, various scholars have accentuated the nestedness of our society, culture, and economy within the environment (e.g., 
Giddings, Hopwood, \& O’Brien, 2002; Griggs, Stafford-Smith, Gaffney, Rockström, Öhman, Shyamsundar, \& Noble, 2013; Waas, Hugé, Verbruggen, \& Wright, 2011).

As a major player in the global economy, the tourism industry is constantly pressured by opposite agendas of preserving the natural and cultural heritage while supporting development activities and increasing profits (Fenton-Keane, 2015). As a result, the environment has become a tool through which nature is transformed for resource management. Nature-based tourism is highly dependent on biodiversity and, according to Gössling (2018), two lines of research address this relationship. First, ecosystems form landscapes and habitats that create the basis for recreation and leisure tourism experiences as well as different tourism attractions, such as natural parks, botanical gardens, and zoos. Second, research has examined the tourism impact on biodiversity by highlighting either negative aspects or positive conservation issues and thus uncovering a complex interrelationship.

The tourism industry has the responsibility to minimize its negative impacts, but also the opportunity to help to solve environmental problems by providing tourism experiences that involve environmental education and promote changes in humans' everyday behavior and lifestyle (Ballantyne \& Packer, 2011; Force, Manuel-Navarrete, \& Benessaiah, 2018). Gössling (2018) has, however, questioned the long-lasting effects of studies on tourism and biodiversity conservation and called for alternative solutions. As there are no simple answers, it is crucial that all actors do their share for the common goal. Markwell (2018) insisted that the tourism industry's responsibility is to do much more than offer packages for "last-chance tourism" and that the dialogue between scholars, practitioners, and tourists needs to be encouraged to create tourism that truly respects nature.

This paper reviews the potential of universities to advance environmental sustainability through nature-based science tourism. First, we address timely topics related to the current changes facing academia, namely the pressure to increase societal effectiveness, science democratization, and environmental sustainability. Second, we define science tourism and nature-based tourism in order to discuss the current and potential role of universities in increasing their societal interaction through science tourism. Third, we evaluate the potential of nature-based science tourism to affect tourists' environmental knowledge, attitudes and behavior. Based on these discussions, we argue that besides producing scientific knowledge on the biodiversity crisis or climate change, universities and scientists could take a stronger stand on shaping these large audiences' attitudes and behavior regarding environmental sustainability. We suggest that science tourism offers a potential channel for academia to enhance environmental sustainability but also a useful tool for highlighting the importance of scientific research and engaging the public in science.

\section{Opening the doors of academia}

Universities have always played a significant role in societies by creating knowledge and transferring it to students and societies. These functions still form the core of modern universities, but during the past decades the focus has moved towards fostering economic growth and pur- 
suing socio-economic goals (e.g., Jones, McCarney, \& Skolnik, 2016). Globalization has transformed knowledge production processes and the academic profession (Huang, Finkelstein, \& Rostan, 2013). Universities have entered a transition characterized by an unstable financial situation, market pressures, and a new public policy environment (Ramsey \& Wesley, 2015). The financial situation of universities has dramatically changed also in Finland due to severe cuts in government funding (Hämeri, 2018). Market pressures include major changes in both supply and demand of higher education, requiring competitive responses from institutions (Ramsey \& Wesley, 2015). University education has become a global public good, leading to increased customer focus and fierce international competition (Sedlacek, 2013) as students and scholars now move across universities and continents, creating a truly multicultural learning environment (Huang et al., 2013). The forms of education have also changed along with new teaching methods, digitalization, and the trend towards mass education (Bleiklie \& Kogan, 2007).

Universities are also facing the pressure of ever-increasing societal expectations and a broader focus on community engagement, often without allocated resources (Ramsey \& Wesley, 2015). The changing relationship between science and society is shaking up academia, especially in Europe, involving timely debates on science popularization, science democratization, open science, and citizen science (Stilgoe, Lock, \& Wilsdon, 2014). Elam and Bertilsson (2003) argued that in $20^{\text {th }}$ century Europe, science was occasionally communicated directly to the public, but the public communicated with science only through government channels. In the $21^{\text {st }}$ century, science has strongly re-entered society to support and sustain collective innovation, giving way to the democratization of science (Elam \& Bertilsson, 2003).

Already 30 years ago, Durant, Evans, and Thomas (1989) asked: Why should we promote the public understanding of science? This debate has ever since gained both policy and practical significance, while the focus has gradually shifted from public understanding of science to public engagement with science (Stilgoe et al., 2014). While the former is based on science dissemination and the latter on dialogue, Burns (2016) argued that all science communication is bound to contain both dissemination and engagement. Regarding future development and research, Stilgoe et al., (2014) called for new platforms and spaces for science engagement as well as renewed enthusiasm for open science.

The openness of science, which has its roots in the $17^{\text {th }}$ century, has recently become a disruptive phenomenon, especially in Europe, with intensive debates on advancing open access, open data, and open science (David, 2008; Stilgoe et al., 2014). Due to the lack of a formal definition, a literature review by Vicente-Sáez and Martínez-Fuentes (2018) suggested that open science is transparent and accessible knowledge that is shared and developed through collaborative networks. The drive for open science is a significant contemporary dynamic of science in general, but also provides opportunities for scholars and advocates of public engagement of science (Stilgoe et al., 2014).

The citizen science movement, in turn, takes science democratization even further by bringing science and the public closer together (Irwin, 1995). It is understood as public participation in scientific research by members of the public partnering with professional scientists to collectively gather, submit, or analyze large quantities of data (e.g., Bonney, 1996). The once novel 
idea has now become mainstream as each year more people are involved in scientific investigation through more widespread, accessible, and rewarding projects (Bonney, Phillips, Ballard, \& Enck, 2016).

\section{Towards environmental sustainability through university education}

Due to their societal effectiveness, universities are considered as forerunners in advancing sustainable development within their communities and the wider society (e.g., Christie et al., 2015; $\mathrm{Wu} \&$ Shen, 2016). In the early 2000s, research on university sustainability focused mainly on campus greening operations and the management of universities' ecological footprint, but during the past decade the interest has shifted towards pedagogy, learning, and instruction as well as community outreach and corporate social responsibility (Wals, 2014; Wu \& Shen, 2016).

Teaching related to sustainable development is generally discussed through specific educational frameworks, of which the most important are: science education, environmental education, and education for sustainable development ${ }^{1}$. Whereas science education focuses primarily on teaching knowledge and skills, the latter two concentrate on the incorporation of values and/or changing behaviors (Wals, Brody, Dillon, \& Stevenson, 2014). All approaches have been applied in higher education (Wu \& Shen, 2016) and - despite somewhat passionate debates regarding their superiority - their overlapping and complementary nature have been well demonstrated (e.g., Littledyke, 2008; Wals et al., 2014).

As human behavior is extremely complex, no definite answer has yet been found to the profound question of science education and environmental education: Why do people act environmentally? (Kollmuss \& Agyemann, 2002). Research in environmental psychology has endeavored to specify the determinants of humans' pro-environmental behavior through empirical studies focusing on the connections between cognitive (e.g., knowledge), psychosocial and/or affective (e.g., attitudes and concern), and demographic (e.g., age and gender) factors (Gifford $\&$ Nilsson, 2014). The associations between these variables seem to vary from direct to indirect and from strong to weak to non-significant, depending on the sample, the site, and the measurement instruments used (Ardoin, Wheaton, Bowers, Hunt, \& Durham, 2015).

Despite the complexity and somewhat contradictory evidence, environmental knowledge is usually considered as a necessary condition for pro-environmental behavior, but not sufficient on its own (Bamberg \& Möser, 2007; Kaiser \& Fuhrer, 2003; Kollmuss \& Agyemann, 2002; Rickinson, 2001; Wiek, Withycombe, \& Redman, 2011). Sustainable behavior seems to necessitate at least three types of knowledge: system, action-related, and effectiveness (Frick, Kaiser, \& Wilson, 2004; Kaiser \& Fuhrer, 2003; Levy, Orion, \& Leshem, 2018).

The level of young people and students' factual environmental knowledge is often found to be relatively low and inconsistent (Rickinson, 2001; Vicente-Molina, Fernández-Sáinz, \& Izagirre-Olaizola, 2013); students' difficulties in understanding environmental phenomena and processes have also been reported (Rickinson, 2001). Regarding adults, the main challenge is not so much the low level of scientific understanding, which seems to have improved steadily,

1 also referred to as sustainability education or education for sustainable development 
but other factors that influence whether environmental or scientific knowledge advances environmental attitudes and behaviors (Bauer, 2009). For instance, even if a person's level of scientific knowledge is high, but his/her trust in scientists to provide reliable information about the environment is low, his/her environmental concern remains low (Malka, Krosnick, \& Langer, 2009). Evidently, forming a link between knowledge generation and knowledge dissemination to current and future decision-makers and the public is considered as one of the key tasks of higher education in both promoting sustainable development and impacting society at large (Barth \& Rieckmann, 2016; Waas, Verbruggen, \& Wright, 2010).

\section{Scientific knowledge dissemination through science tourism}

The combination of science and tourism seems somewhat unusual. Universities and scientific knowledge are frequently linked to regional development and innovation and considered to have a significant contribution to the economic, social, and cultural vitality of the surrounding region (see Höyssä, 2012). However, the role of universities in relation to the local tourism industry is very rarely discussed, even though global tourism has become a significant source of wealth and employment. Obviously, universities provide scientific tourism knowledge for the industry (Hoarau \& Kline, 2014; Xiao \& Smith, 2007) and boost local tourism through organizing scientific conferences or renting out student accommodation (Holloway \& Humphreys, 2016). But, in a wider sense universities are neither considered as focal actors of the tourism industry nor potential providers of tourism experiences.

With a closer look, however, universities and the tourism industry are already linked together. Researchers and students increasingly travel for scientific inquiry (Slocum, Kline, \& Holden, 2015) or educational travel (Ritchie, Carr, Cooper, 2003; Stone \& Petrick, 2013), and leisure tourists are keen to visit famous universities and scientific landmarks, such as museums, laboratories, and observatories (Bourlon \& Torres, 2016).

According to previous literature, the link between science and tourists is twofold. First, scientific tourism traditionally refers to international travel for scientific enquiry - a phenomenon that has its roots in the scientific discovery and exploration of $19^{\text {th }}$ century Europe (Slocum et al., 2015). According to Holden (2015), scientific tourism is scarcely researched and lacks clear definition, but it is either seen as a form of alternative tourism or equated with conservation volunteer tourism.

In the second stream of literature, which we call here science tourism, science and scientific knowledge are understood as resources for tourism experiences and product development (Bourlon \& Torres, 2016; Räikkönen \& Suni, forthcoming). Scientific knowledge is either passively shared with tourists or actively produced together with them to co-create experience value (cf. Räikkönen \& Suni, forthcoming). The increasing demand for science tourism (e.g., Hoarau \& Kline, 2014) depicts the nature of the experience economy and the shift towards the transformation economy in which individuals are pursuing meaningful experiences and self-actualization through, for example, environmental awareness and intellectual growth (cf. Pine \& Gilmore, 1999; Räikkönen \& Grénman, 2017). As a form of niche tourism, Robinson and 
Novelli (2005) placed education and research under cultural tourism while other researchers have linked science experiences to nature-based or ecotourism, adventure tourism, and volunteer tourism (e.g., Hall \& Saarinen, 2010; Laarman \& Perdue, 1989; West, 2008).

As illustrated in Figure 1, scientific tourism and science tourism, which both deal with scientific knowledge and learning (see Gössling, 2017; Hoarau \& Kline, 2014), can be understood as extensions of educational tourism (Ritchie et al., 2003). Educational tourism has its roots in the Grand tours of the $17^{\text {th }}-19^{\text {th }}$ centuries and is also divided into two types (Ritchie et al., 2003). In university, college, and school tourism formal learning dominates, and tourism experiences are secondary, while edu-tourism refers to more general travel for education, including, for example, youth study tours (Ritchie et al., 2003). Figure 1 highlights the differences between these four types of tourism based on their focus on education or science as well as the dominance of tourism experiences or science and education.

\begin{tabular}{|c|c|c|}
\hline & $\begin{array}{l}\text { Education, knowledge, } \\
\text { and skills }\end{array}$ & $\begin{array}{c}\text { Scientific knowledge } \\
\text { and skills }\end{array}$ \\
\hline $\begin{array}{c}\text { Tourism experiences } \\
\text { first }\end{array}$ & $\begin{array}{c}\text { Edu-tourism } \\
\rightarrow \text { Travel for education }\end{array}$ & $\begin{array}{c}\text { Science tourism } \\
\rightarrow \text { Science as a resource of } \\
\text { tourism experiences }\end{array}$ \\
\hline $\begin{array}{c}\text { Science and education } \\
\text { first }\end{array}$ & $\begin{array}{l}\text { University, college \& } \\
\text { school tourism } \\
\rightarrow \text { Students as travelers }\end{array}$ & $\begin{array}{c}\text { Scientific tourism } \\
\rightarrow \text { Scientists as travelers }\end{array}$ \\
\hline
\end{tabular}

Figure 1. Science tourism versus educational tourism.

It needs to be noted that science tourism is as wide as science itself. It can be related to natural sciences (e.g., biology and ecology), social sciences (e.g., sociology and psychology), or even formal sciences (e.g., mathematics and logic). As the current study focuses on nature-based tourism and its role in promoting environmental sustainability, the focus is on natural sciences that study nature, natural phenomena, and the natural basis of sustainable development. However, we acknowledge that meanings related to nature vary across time, space, and culture, and, moreover, nature is as much a product of history and culture as it is a product of biophysical and ecological processes (Markwell, 2018).

\section{Disseminating scientific knowledge on biodiversity and environmental sustainability through nature-based science tourism}

Nature-based tourism is an umbrella term for tourism activities that enable tourists to get in touch with nature through, for instance, ecotourism and wildlife tourism but also adventure, captive, extractive, or even some types of health tourism (Hall \& Williams, 2008). According to Goodwin (1996), nature-based tourism uses undeveloped natural resources, including landscapes, habitats, water features, and species to enjoy natural areas or wildlife. In nature-based tourism, the natural environment forms the key attraction of tourism, and the experience value is primarily 
concerned with the direct enjoyment of some relatively undisturbed phenomenon of nature (cf. Fredman \& Tyrväinen, 2010). Spenceley (2008) noted that nature-based tourism often takes place within protected areas dedicated primarily to the protection and enjoyment of natural or cultural heritage, the maintenance of biodiversity, and ecological life-support services.

Here we discuss nature-based tourism through more specifically defined concepts of ecotourism and wildlife tourism. The International Ecotourism Society (TIES, 2015) has defined ecotourism as responsible travel to natural areas that conserves the environment, sustains the well-being of the local people, and involves interpretation and education. According to Fenton-Keane (2015), the term ecotourism was first introduced in 1983 by Hector Ceballos-Lascuráin, who described it as travel to relatively undisturbed natural areas with the specific object of studying, admiring, and enjoying the scenery and its wild plants and animals as well as any existing cultural aspects found in these areas. Interestingly, ecotourism includes requirements for education, conservation, and respect of cultures (Reynolds \& Braithwaite, 2001) and aims to facilitate and support pro-conservation attitudes, knowledge, and behavior among visitors (Ballantyne \& Packer, 2011). The original definition of ecotourism implies a scientific, aesthetic, or philosophical approach, although the ecotourist is not required to be a professional scientist, artist, or philosopher (see Fenton-Keane, 2015).

Weaver (2005) discussed the educational impact of ecotourism and differentiated minimalist and comprehensive ecotourism experiences. The minimalist type emphasizes superficial learning opportunities focused on charismatic megafauna, with mainly site-specific and status quo-oriented sustainability objectives. The comprehensive type, in turn, adopts a more holistic approach to attractions and interpretation that fosters environmental enhancement, deep understanding, and transformation of behavior.

Along with ecotourism, wildlife tourism is also a distinct form of nature-based tourism, focusing on tourism based on interactions with wildlife. According to Reynolds and Braithwaite (2001), wildlife tourism is essentially about increasing the probability of positive encounters with wildlife for visitors while protecting the wildlife resource. Wildlife tourism has also been portrayed as a potential tool for wildlife conservation, even though the values of conservation, animal welfare, visitor satisfaction, and economic profitability are often in conflict (Reynolds \& Braithwaite, 2001). Wildlife tourism is divided into consumptive and non-consumptive practices. Consumptive wildlife tourism refers to hunting or shooting game animals or fishing for sports fish, either in natural areas or in areas created for these purposes (Lovelock, 2008). Non-consumptive wildlife tourism, in turn, is human recreational engagement with wildlife wherein the focal organism is not purposefully removed or permanently affected by the engagement (Duffus \& Dearden, 1990).

In the early days of wildlife tourism, consumptive practices dominated, but recently non-consumptive practices have become increasingly popular (Lovelock, 2008). For example, birding evolved during the $20^{\text {th }}$ century from an unusual hobby into a global phenomenon contributing to the tourism industry, ornithology, and bird conservation (Puhakka, Salo, \& Sääksjärvi, 2011). Similar development now applies to mammal watching, and thus Dinets and Hall 
(2018) suggested actions for how professional mammalogists and the amateur community can better work together to promote both science and conservation.

As illustrated in Figure 2, both ecotourism and wildlife tourism seem to move nature-based tourism closer to nature-based science tourism, but there is still a long way to go to nature-based citizen science. While in nature-based science tourism natural scientists mediate scientific knowledge to tourists in order to co-create experience value, in nature-based citizen science new knowledge is actually produced together with scientists and tourists.

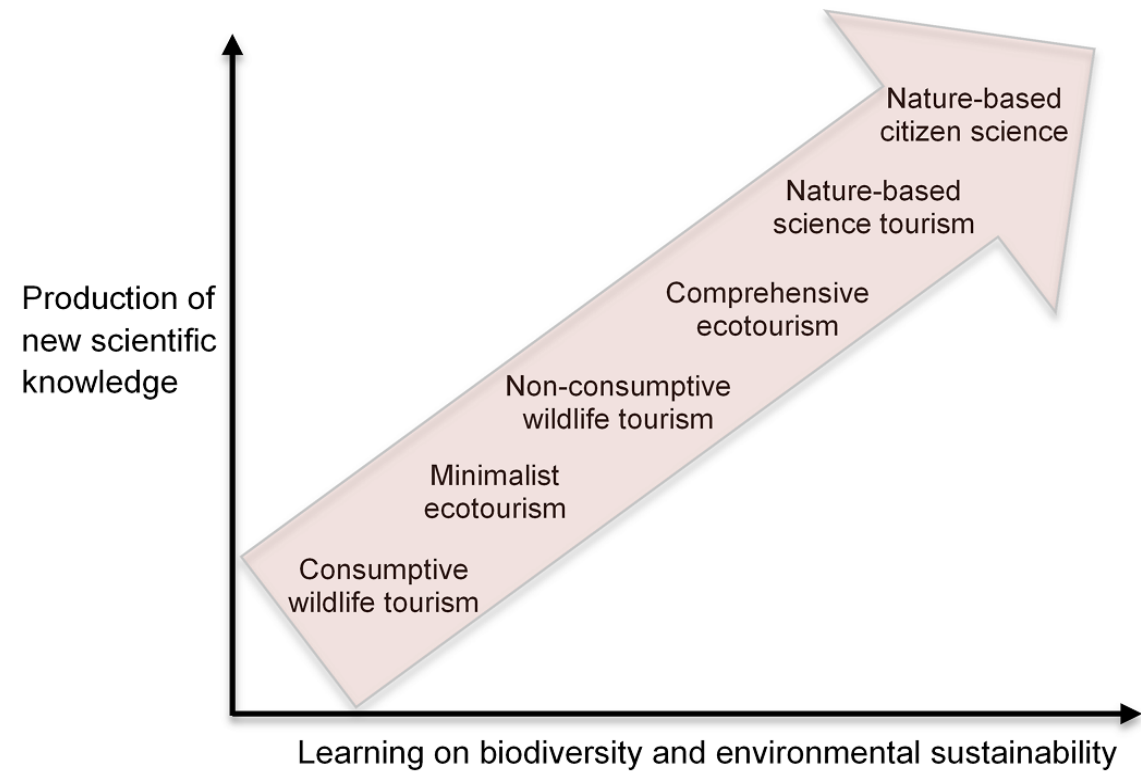

Figure 2. The intensification of scientific dimension in different forms of nature-based tourism.

Previous literature has touched upon the scientific dimension of nature-based tourism and clearly acknowledged that scientists can support nature-based tourism by bringing scientific content to, for example, whale watching (Hoarau \& Kline, 2014), birding (Puhakka et al., 2011), and mammal-watching tours (Dinets \& Hall, 2018). A profound discussion on the relationship between science and nature-based tourism is presented by Hoarau and Kline (2014), who focused on the absorption of scientific knowledge into tourism innovation processes by examining scientists as a source of knowledge in whale-watching tourism. They reviewed various forms of interaction between scientists and the tourism industry, such as providing knowledge and materials (Donnelly, Katzner, Gordon, Gompper, Redpath, Garner, \& Pettorelli, 2011; Rodger \& Moore, 2004), bringing credibility (Bertella, 2011; Coghlan, 2008), conducting research (Coghlan, 2008) and disseminating results as well as creating social relationships needed for research funding (Rodger, Moore, \& Newsome, 2010). Based on an empirical study, Hoarau and Kline (2014) suggested that intensive interaction with researchers can increase organizational learning and development, bring science and industry closer together, and co-create business 
opportunities and innovations based on scientific knowledge. Finally, they called for further research on how science and industry could work more closely together. Even though scientists were in the spotlight of the study, their role seemed to remain at the level of supporting the tourism industry instead of being an active part of it.

More profound interaction between scientists and tourists would mean a major step towards citizen science, which has become a popular means of conducting scientific research and enhancing public understanding of and engagement with science (Bonney et al., 2016). Thiel et al. (2014) examined over two hundred studies in which professional scientists collaborated with volunteers in a wide range of marine investigations and concluded that the contribution of citizen scientists greatly enhanced research capacity, providing an increased workforce over extensive spatial and intensive temporal scales at comparatively moderate costs. They suggested that citizen science should be considered as a powerful tool for generating and spreading scientific knowledge, as sharing knowledge between volunteer participants and professional scientists improved communication, trust, and capacity building, facilitating efficient collaboration in conservation initiatives (Thiel, Penna-Díaz, Luna-Jorquera, Salas, Sellanes, \& Stotz, 2014). However, more research is needed to uncover how participation in citizen science projects would affect value co-creation in tourism experiences.

\section{Can nature-based science tourism enhance environmental sustainability?}

Even though the impacts of science tourism have not been directly examined, we have endeavored to evaluate whether nature-based science tourism can impact environmental sustainability by leaning on previous knowledge regarding both nature-based tourism and citizen science. Many studies have addressed the potential of tourism and nature-based tourism to promote environmentally sustainable behaviors through education. Research on the educative benefits of travel and tourism in general is relatively scarce, albeit expanding (Stone \& Petrick, 2013). In their review, Stone and Petrick (2013) found that the majority of the studies focused on study abroad, whereas domestic tourism, short-term travel, and vacations have received very little attention. Moreover, they stated that research has focused mainly on cross-cultural competence and personal change instead of learning outcomes with academic or other orientations.

According to previous literature, nature-based tourism experiences have the potential to inspire and nurture interest in biology and natural history as well as motivate tourists to adopt pro-environmental behaviors (Ardoin et al., 2015; Ballantyne, Packer, Hughes, \& Dierking, 2007; McGehee \& Norman, 2001). However, in practice, it seems that many eco- and wildlife tourism experiences are failing to deliver a strong conservation message (Ballantyne \& Packer, 2011).

Ardoin et al. (2015) searched for empirical evidence on whether nature-based tourism induces positive changes to tourists' environmental knowledge, attitudes, or behaviors by reviewing 30 comparable empirical articles published on the topic during 1995-2013. Notably, most of these studies were carried out in publicly-owned protected areas, over half focused on marine tourism, and two-thirds examined nature-based tourism in Australia. According to the results, most evidence was available on outcomes related to tourists' new environmental knowledge, 
as all the studies that touched upon the issue reported at least some positive changes. More precisely, five out of the seven studies addressing the post-visit effects of nature-based tourism experiences found that the knowledge change lasted for at least one month, and, moreover, post-visit support, such as fact sheets, links to informative websites, or family activities, increased this effect (Ardoin et al., 2015). Findings related to environmental attitudes and behaviors were much more inconsistent, and the review indicated that many studies called for more high-quality research focusing on interpretation from trained mediators to increase tourists' environmental knowledge, attitudes, and behavior. The scholars suggested that service providers should offer their visitors action-related information, direct contacts with wildlife, on-site opportunities to act, and time for reflection. Interestingly, the participants with the lowest levels of environmental knowledge, attitudes, and behaviors were particularly likely to exhibit significant changes in all domains (Ardoin et al., 2015).

Citizen science programs are often considered to impact participants by, for example, advancing their conservation literacy, scientific knowledge, and scientific reasoning skills, yet there is uncertainty regarding the extent to which these initiatives change actual behavior (Bell et al., 2008; Jordan, Gray, Howe, Brooks, \& Ehrenfeld, 2011; Newman, Wiggins, Crall, Graham, Newman, \& Crowston, 2012). Research combining tourism and citizen science is scarce, yet Dinets and Hall (2018), based on positive experiences from birding, discussed the possibilities of mammal watching to achieve similar contributions to tourism, science, and conservation. While evaluating the wider effectiveness of citizen science, Bonney et al. (2016) noted that all citizen science projects are not even intended to democratize science or to produce outcomes beyond answering scientific questions. In addition, Jordan et al. (2011) indicated that potential conflicts between scientific and educational goals as well as the motivation of participants need to be considered when designing citizen science programs.

On a more philosophical level, however, citizen science has been linked to the idea of hopeful tourism, which calls for a values-led humanist paradigm change in tourism and a commitment to the greater good (see Pritchard, Morgan, \& Ateljevic, 2011). Brosnan, Filep, \& Rock (2015) suggested that through nature-based citizen science projects tourists can contribute to research that helps mitigate current challenges, such as the biodiversity crisis and climate change. Furthermore, they argued that citizen science and hopeful tourism share common ground through their emphasis on ethics and morality, requirements for greater collaboration between stakeholders to address the challenges of sustainable development, as well as the empowerment of marginalized and underprivileged groups in knowledge production. Regarding future research, the authors also highlighted the urgency of issues related to climate change that damage humans, species, and environments and the role of citizen science tourism experiences in promoting environmental awareness, compassion, and activism, yet stressed the importance of positive and hopeful approaches as the relentless negativism about the future is likely to lead to despair (Brosnan et al., 2015). 


\section{Conclusions and discussion}

This paper reviewed the potential of universities to advance environmental sustainability through nature-based science tourism. Based on previous literature, we argue that science tourism - especially nature-based science tourism - offers one possible alternative for universities to respond to the rapidly changing global environment in which they operate. Besides the financial situation, which challenges universities to pursue alternative funding streams to secure their effective research and education, there is an increasing pressure to advance the societal role of universities and scientific knowledge through active dissemination and public engagement. Above all, the current environmental challenges, such as the biodiversity crisis and climate change, urge universities to push their limits in advancing sustainable development through all possible - and yet unknown - means.

The tourism sector is a major player in the global economy and also responsible for damaging biodiversity, disturbing ecosystems, and accelerating climate change. Universities around the world conduct research on sustainable tourism management, but other than that their role in the tourism sector is nearly non-existent. With this review, we have endeavored to highlight that universities and scientists could have a much more significant role in the tourism industry and especially in nature-based tourism. In line with the shift from science dissemination towards public engagement with science, this means direct and intensive interaction - not only providing scientific knowledge and learning to touristsbut also conducting research with them and involving them in creating new scientific knowledge. We argue that universities have the power to offer interesting and eye-opening science tourism experiences and inspiring encounters with scientists that challenge tourists to think and act critically, creatively, and responsibly.

The current review has concentrated on nature-based tourism and natural sciences, but the principles of science tourism can and should be applied to social sciences and formal sciences as well. Therefore, more research is needed to address how science tourism can be used in promoting social, cultural, and economic dimensions of sustainable development.

Change always comes with resistance to change. Universities are the oldest cultural institutions of current societies (Kolbe, 2012), and the long academic tradition needs to be nurtured, while new ideas are also essential in maintaining and advancing scientific research, education, and societal interaction. Environmental sustainability is a good example of this contradiction. It is quite clear that environmentally sustainable development necessitates multidisciplinary approaches and profound, values-related discussions. Some academics and university leaders may resist these approaches in practice, due to fears of indoctrination, i.e., teaching students how to think or what values to hold to (Christie et al., 2015; Wals \& Jickling, 2002). Other possible fears may be related to the economic goals of science tourism activities. To overcome these fears, universities need to encourage open, pluralistic discussions related to the goals of science tourism, so that the principles and integrity of scientific thinking are retained and scientific information is available for all, not just for paying customers.

We acknowledge that there is also a need for discussion regarding the wider agendas of universities and academics, as learning on sustainable development requires reflection on values (cf. Barth, Godemann, Rieckmann, \& Stoltenberg, 2007; Bonnett, 2002; Wiek et al., 2011). 
Furthermore, in theoretical discussions, sustainable development is a highly contested concept and often manifested in political, value-laden debates. From this perspective, avoiding value debates reduces the effectiveness of sustainable development as a transformative concept. As the discussion on values is also increasingly called for in the tourism sector, it should be included in the educational efforts of science tourism with sustainable development goals.

Science tourism development is likely to cause resistance also in scientists, who face enormous pressure to conduct and publish high-quality research and obtain increasingly competitive research funding. However, science dissemination and societal interaction are seen as increasingly important parts of the academic profession, and models for measuring and crediting these activities are currently being developed. Fundamentally, however, the motivation to engage in science tourism, needs to come from academics themselves. We consider that upcoming scholars have an innate understanding of the importance of branding themselves as professional academics, which involves active engagement with the public and society. They also seem to have an increasing interest in including sustainability issues in their work (e.g., Christie et al., 2015). Moreover, science popularization is increasingly included in the curricula of future scholars, which is also likely to close the gap between scientists and the public, more precisely between scientific and popular language, which has been identified as a challenge for science tourism (cf. Hoarau \& Kline, 2014).

\section{Limitations and future research}

As with any study, certain limitations need to be addressed. First, science tourism development has emerged as a result of various changes that are taking place in our current era. Our attempt to cover at least some of the major trends is likely to lead to a somewhat superficial and incomplete synthesis of several overlapping paradigms. Our multidisciplinary research team worked in tight cooperation to overcome this limitation, yet we suggest that future research pursues a more profound understanding of the possibilities and challenges of science tourism development.

Second, in this paper we have focused on a rather simple idea of knowledge dissemination as the primary means of promoting learning in science tourism. Yet, we acknowledge that a transformation towards environmentally sustainable development requires a much more comprehensive understanding of education and learning. The research and discussions in the fields of science education, environmental education, and education for sustainable development provide possible future paths for studying and developing teaching and learning experiences related to science tourism that comprehensively support the goals of transformative learning related to sustainable development. Examples of theoretical and practical educational approaches with the potential to inform multidisciplinary, experiential and outdoor-focused nature-based science tourism include lifelong and informal learning (e.g., Stone \& Petrick, 2013), experiential learning (e.g., Kolb, 1984), and systemic and holistic learning (e.g., Lugg, 2007). Theories of social learning (Wals, 2007) could provide perspectives for exploring the potential for reciprocal learning between tourists and researchers in the context of science tourism. Tourism and 
leisure experiences achieved in out-of-school learning settings, such as botanical gardens and museums, could serve as the basis for developing pedagogy for science tourism (cf. Ballantyne \& Packer, 2005; Dunkley, 2016; Sellmann \& Bogner, 2013; Zelenika, Moreau, Lane, \& Zhao, 2018).

Finally, attractions such as botanical gardens and aquariums that use science as a resource for nature-based tourism and aim to promote environmental sustainability among visitors, have been criticized for attracting visitors who already have a high interest in the environment and a relatively high level of scientific knowledge as well (Ballantyne, Packer, \& Falk, 2011). Therefore, it is crucial to extend the audience of science tourism beyond current visitors with marketing operations that target more diverse customer segments. Science education that focuses on experiential learning and concretizing complex scientific phenomena in the natural environment with scientists can foster long-lasting environmental knowledge and positive environmental attitudes and behaviors (Behrendt \& Franklin, 2014; Farmer, Knapp, \& Benton, 2007). We suggest that science tourism can result in similar research results, but research on long-term effects of science tourism as well as its ability to increase people's trust in scientists and scientific research is highly welcomed.

\section{References}

Ardoin, N. M., Wheaton, M., Bowers, A. W., Hunt, C. A., \& Durham, W. H. (2015). Nature-based tourism's impact on environmental knowledge, attitudes, and behavior: A review and analysis of the literature and potential future research. Journal of Sustainable Tourism, 23, 838-858. https://doi.org/10.1080/09669582.2015.1024258

Ballantyne, R., \& Packer, J. (2005). Promoting environmentally sustainable attitudes and behaviour through free-choice learning experiences: What is the state of the game? Environmental Education Research, 11, 281-295. https://doi.org/10.1080/13504620500081145

Ballantyne, R., \& Packer, J. (2011). Using tourism free-choice learning experiences to promote environmentally sustainable behaviour: The role of post-visit 'action resources'. Environmental Education Research, 17, 201-215. https://doi.org/10.1080/13504622.2010.530645

Ballantyne, R., Packer, J., \& Falk, J. (2011). Visitors' learning for environmental sustainability: Testing short-and long-term impacts of wildlife tourism experiences using structural equation modelling. Tourism Management, 32, 1243-1252. https://doi.org/10.1016/j.tourman.2010.11.003

Ballantyne, R., Packer, J., Hughes, K., \& Dierking, L. (2007). Conservation learning in wildlife tourism settings: Lessons from research in zoos and aquariums. Environmental Education Research, 13, 367-383. https://doi.org/10.1080/13504620701430604

Bamberg, S., \& Möser, G. (2007). Twenty years after Hines, Hungerford, and Tomera: A new meta-analysis of psycho-social determinants of pro-environmental behaviour. Journal of Environmental Psychology, 27, 14-25. https://doi.org/10.1016/j.jenvp.2006.12.002

Barth, M., Godemann, J., Rieckmann, M., \& Stoltenberg, U. (2007). Developing key competencies for sustainable development in higher education. International Journal of Sustainability in Higher Education, 8, 416-430. https://doi.org/10.1108/14676370710823582 
Barth, M., \& Rieckmann, M. (2016). State of the art in research on higher education for sustainable development. In M. Barth, G. Michelsen, M. Rieckmann \& I. Thomas (Eds.), Routledge handbook of higher education for sustainable development (pp. 100-113). London: Routledge.

Bauer, M. W. (2009). The evolution of public understanding of science - discourse and comparative evidence. Science, Technology and Society, 14, 221-240. https://doi. org/10.1177/097172180901400202

Behrendt, M., \& Franklin, T. (2014). A review of research on school field trips and their value in education. International Journal of Environmental and Science Education, 9, 235-245.

Bell, S., Marzano, M., Cent, J., Kobierska, H., Podjed, D., Vandzinskaite, D., ...Muršič, R. (2008). What counts? Volunteers and their organisations in the recording and monitoring of biodiversity. Biodiversity and Conservation, 17, 3443-3454. https://doi.org/10.1007/s10531-008-9357-9

Bertella, G. (2011). Wildlife tourism and natural sciences knowledge: Challenges and critical factors. Scandinavian Journal of Hospitality and Tourism, 11, 97-114. https://doi.org/10.1080/1502225 0.2011 .540794

Bleiklie, I., \& Kogan, M. (2007). Organization and governance of universities. Higher Education Policy, 20, 477-493. https://doi.org/10.1057/palgrave.hep.8300167

Bonnett, M. (2002). Education for sustainability as a frame of mind. Environmental Education Research, 8, 9-20. https://doi.org/10.1080/13504620120109619

Bonney, R. (1996). Citizen science: A lab tradition. Living Bird, 15(4), 7-15.

Bonney, R., Phillips, T. B., Ballard, H. L., \& Enck, J. W. (2016). Can citizen science enhance public understanding of science? Public Understanding of Science, 25(1), 2-16. https://doi. org/10.1177/0963662515607406

Bourlon, F., \& Torres, R. (2016). Scientific tourism, a tool for tourism development in Patagonia. Retrieved March 11, 2019, from https://labexitem.hypotheses.org/177

Brosnan, T., Filep, S., \& Rock, J. (2015). Exploring synergies: Hopeful tourism and citizen science. Annals of Tourism Research, 53, 96-98. https://doi.org/10.1016/j.annals.2015.05.002

Brundtland, G. H., Khalid, M., \& Agnelli, S. (1987). Our common future. In M. K. Tolba \& A. K. Biswas (Eds.), Earth and us. Populations-Resources-Environment-Development. United Nations Environment Programme. Butterworth-Heinemann: New York.

Burns, M. (2016). Political implications of science popularisation strategies: Frontiers of Science. Public Understanding of Science, 25, 518-530. https://doi.org/10.1177\%2F0963662515597186

Christie, B. A., Miller, K. K., Cooke, R., \&White, J. G. (2015). Environmental sustainability in higher education: What do academics think? Environmental Education Research, 21, 655-686. https:// doi.org/10.1080/13504622.2013.879697

Coghlan, A. (2008). Exploring the role of expedition staff in volunteer tourism. International Journal of Tourism Research, 10, 183-191. https://doi.org/10.1002/jtr.650

David, P. A. (2008). The historical origins of 'open science': An essay on patronage, reputation and common agency contracting in the scientific revolution. Capitalism and Society, 3(2). https://doi.org/10.2202/1932-0213.1040 
Dessein, J., Soini, K., Fairclough, G., \& Horlings, L. (2015). Culture in, for and as Sustainable Development. Conclusions from the COST Action IS1007 Investigating Cultural Sustainability. University of Jyväskylä.

Diaz, S. et al. (2019). Summary for policymakers of the global assessment report on biodiversity and ecosystem services of the Intergovernmental Science-Policy Platform on Biodiversity and Ecosystem Services. Advance Unedited Version 6 May 2019. Retrieved May 14, 2019, from https://www.ipbes.net/ system/tdf/spm_global_unedited_advance.pdf?file=1\&type=node\&id=35245

Dinets, V., \& Hall, J. (2018). Mammalwatching: A new source of support for science and conservation. International Journal of Biodiversity and Conservation, 10(4), 154-160. https://doi.org/10.5897/ IJBC2017.1162

Donnelly, R. E., Katzner, T., Gordon, I. J., Gompper, M. E., Redpath, S., Garner, T. W. J., ...Pettorelli, N. (2011). Putting the eco back in ecotourism. Animal Conservation, 14, 325-327. https://doi.org/10.1111/j.1469-1795.2011.00468.x

Duffus, D. A., \& Dearden, P. (1990). Non-consumptive wildlife-oriented recreation: A conceptual framework. Biological Conservation, 53, 213-231. https://doi.org/10.1016/0006-3207(90)90087-6

Dunkley, R. A. (2016). Learning at eco-attractions: Exploring the bifurcation of nature and culture through experiential environmental education. The Journal of Environmental Education, 47, 213-221. https://doi.org/10.1080/00958964.2016.1164113

Durant, J. R., Evans, G. A., \& Thomas, G. P. (1989). The public understanding of science. Nature, 340, 11-14. https://doi.org/10.1038/340011ao

Elam, M., \& Bertilsson, M. (2003). Consuming, engaging and confronting science: The emerging dimensions of scientific citizenship. European Journal of Social Theory, 6, 233-251. https://doi.or g/10.1177\%2F1368431003006002005

Farmer, J., Knapp, D., \& Benton, G. M. (2007). An elementary school environmental education field trip: Long-term effects on ecological and environmental knowledge and attitude development. The Journal of Environmental Education, 38(3), 33-42. https://doi.org/10.3200/ JOEE.38.3.33-42

Fenton-Keane, J. (2015). Science and nature discourse in ecotourism. In A. Holden, S. Slocum \& C. Kline (Eds), Scientific tourism: Researchers as travellers (pp. 40-50). Abingdon: Routledge.

Force, A., Manuel-Navarrete, D., \& Benessaiah, K. (2018). Tourism and transitions toward sustainability: Developing tourists' pro-sustainability agency. Sustainability Science, 13, 431-445. https://doi.org/10.1007/s11625-017-0448-y

Fredman, P., \& Tyrväinen, L. (2010). Frontiers in nature-based tourism. Scandinavian Journal of Hospitality and Tourism, 10, 177-189. https://doi.org/10.1080/15022250.2010.502365

Frick, J., Kaiser, F. G., \& Wilson, M. (2004). Environmental knowledge and conservation behavior: Exploring prevalence and structure in a representative sample. Personality and Individual Differences, 37, 1597-1613. https://doi.org/10.1016/j.paid.2004.02.015

Giddings, B., Hopwood. B., \& O’Brien, G. (2002). Environment, economy and society: Fitting them together into sustainable development. Sustainable Development, 10, 187-196. https://doi. org/10.1002/sd.199 
Gifford, R., \& Nilsson, A. (2014). Personal and social factors that influence pro-environmental concern and behaviour: A review. International Journal of Psychology, 49, 141-157. https://doi. org/10.1002/ijop.12034

Goodwin, H. (1996). In pursuit of ecotourism. Biodiversity and Conservation, 5, 277-292. https://doi. org/10.1007/BF00051774

Griggs, D., Stafford-Smith, M., Gaffney, O., Rockström, J., Öhman, M. C., Shyamsundar, P., ...Noble, I. (2013). Policy: Sustainable development goals for people and planet. Nature, 495, 305-307. https://doi.org/10.1038/495305a

Gössling, S. (2017). Tourism, tourist learning and sustainability: An exploratory discussion of complexities, problems and opportunities. Journal of Sustainable Tourism, 26, 292-306. https:// doi.org/10.1080/09669582.2017.1349772

Gössling, S. (2018). Tourism and biodiversity. In C. Cooper, S. Volo, W. C. Gartner \& N. Scott (Eds.), The SAGE handbook of tourism management (pp. 437-447). London: Sage.

Hall, C. M., \& Saarinen, J. (2010). Polar tourism: Definitions and dimensions. Scandinavian Journal of Hospitality and Tourism, 10, 448-467. https://doi.org/10.1080/15022250.2010.521686

Hall, C. M., \& Williams, A. (2008). Tourism and innovation. Abingdon: Routledge.

Hoarau, H., \& Kline, C. (2014). Science and industry: Sharing knowledge for innovation. Annals of Tourism Research, 46, 44-61. https://doi.org/10.1016/j.annals.2014.01.005

Holden, A. (2015). Introduction. In A. Holden, S. Slocum \& C. Kline (Eds), Scientific tourism: Researchers as travellers (pp. 1-5). Abingdon: Routledge.

Holloway, J. C., \& Humphreys, C. (2016). The business of tourism. Harlow: Pearson.

Hopwood, B., Mellor, M., \& O’Brien, G. (2005). Sustainable development: mapping different approaches. Sustainable Development, 13, 38-52. https://doi.org/10.1002/sd.244

Huang, F., Finkelstein, M., \& Rostan, M. (Eds.) (2013). The internationalization of the academy: Changes, realities and prospects. Dordrecht: Springer.

Hämeri, K. (2018). How should universities be funded? Retrieved March 11, 2019, from https://www. helsinki.fi/en/news/higher-education-science-policy/how-should-universities-be-funded

Höyssä, M. (2012). Where science meets its use - Exploring the emergence of the practical relevance of scientific knowledge in the regional context. Turku School of Economics.

Irwin, A. (1995). Citizen science: A study of people, expertise, and sustainable development. London: Routledge.

Jones, G. A., McCarney, P., \& Skolnik, M. L. (2016). Creating knowledge, strengthening nations: The changing role of higher education. University of Toronto Press.

Jordan, R. C., Gray, S. A., Howe, D. V., Brooks, W. R., \& Ehrenfeld, J. G. (2011). Knowledge gain and behavioral change in citizen-science programs. Conservation Biology, 25, 1148-1154. https:// doi.org/10.1111/j.1523-1739.2011.01745.x

Kaiser, F. G., \& Fuhrer, U. (2003). Ecological behavior's dependency on different forms of knowledge. Applied Psychology, 52, 598-613. https://doi.org/10.1111/1464-0597.00153 
Kolb, D. A. (1984). Experiential learning: Experience as the source of learning and development. Englewood Cliffs: Prentice-Hall.

Kolbe, L. (2012). Huipulle ja yhteiskuntaan - oma kulttuuriperintö yliopistojen kilpailuvaltiksi. Tieteessä tapahtuu, 30(4), 27-34.

Kollmuss, A., \& Agyeman, J. (2002). Mind the gap: Why do people act environmentally and what are the barriers to pro-environmental behavior? Environmental Education Research, 8, 239-260. https://doi.org/10.1080/13504620220145401

Laarman, J. G., \& Perdue, R. R. (1989). Science tourism in Costa Rica. Annals of Tourism Research, 16, 205-215. https://doi.org/10.1016/0160-7383(89)90068-6

Leal Filho, W. (2000). Dealing with misconceptions on the concept of sustainability. International Journal of Sustainability in Higher Education, 1, 9-19. https://doi.org/10.1108/1467630010307066

Levy, A., Orion, N., \& Leshem, Y. (2018). Variables that influence the environmental behavior of adults. Environmental Education Research, 24, 307-325. https://doi.org/10.1080/13504622.2016.12 71865

Littledyke, M. (2008). Science education for environmental awareness: Approaches to integrating cognitive and affective domains. Environmental Education Research, 14, 1-17. https://doi. org/10.1080/13504620701843301

Lovelock, B. (Ed.). (2008). Tourism and the consumption of wildlife: Hunting, shooting and sport fishing. Abingdon: Routledge.

Lugg, A. (2007). Developing sustainability-literate citizens through outdoor learning: Possibilities for outdoor education in higher education. Journal of Adventure Education \& Outdoor Learning, 7, 97-112. https://doi.org/10.1080/14729670701609456

Malka, A., Krosnick, J. A., \& Langer, G. (2009). The association of knowledge with concern about global warming: Trusted information sources shape public thinking. Risk Analysis: An International Journal, 29, 633-647. https://doi.org/10.1111/j.1539-6924.2009.01220.x

Markwell, K. (2018). Foreword. In B. S. Grimwood, K. Caton \& L. Cooke (Eds.), New moral natures in tourism. Abingdon: Routledge.

McGehee, N. G., \& Norman, W. C. (2001). Alternative tourism as impetus for consciousness-raising. Tourism Analysis, 6, 239-251. https://doi.org/10.3727/108354201108749872

Newman, G., Wiggins, A., Crall, A., Graham, E., Newman, S., \& Crowston, K. (2012). The future of citizen science: Emerging technologies and shifting paradigms. Frontiers in Ecology and the Environment, 10, 298-304. https://doi.org/10.1890/110294

Pine, J., \& Gilmore, J. (1999). The experience economy: Work is theatre every business a stage. Boston: Harvard Business School Press.

Pritchard, A., Morgan, N., \& Ateljevic, I. (2011). Hopeful tourism: A new transformative perspective. Annals of Tourism Research, 38, 941-963. https://doi.org/10.1016/j.annals.2011.01.004

Puhakka, L., Salo, M., \& Sääksjärvi, I. E. (2011). Bird diversity, birdwatching tourism and conservation in Peru: A geographic analysis. PLoS One, 6(11), e26786. https://doi.org/10.1371/journal. pone. 0026786 
Ramsey, J. R., \&Wesley, M. (2015). Leadership challenges for the university of the 21st century. International Journal of Leadership and Change, 3(1), Article 1.

Reynolds, P. C., \& Braithwaite, D. (2001). Towards a conceptual framework for wildlife tourism. Tourism Management, 22, 31-42. https://doi.org/10.1016/S0261-5177(00)00018-2

Rickinson, M. (2001). Learners and learning in environmental education: A critical review of the evidence. Environmental Education Research, 7, 207-320. https://doi. org/10.1080/13504620120065230

Ritchie, B. W., Carr, N., \& Cooper, C. P. (2003). Managing educational tourism. Clevedon: Channel View Publications.

Robinson, M., \& Novelli, M. (2005). Niche tourism: An introduction. In M. Novelli (Ed.), Niche tourism: Contemporary issues, trends and cases (pp. 1-14). Oxford: Butterworth-Heinemann.

Rodger, K., \& Moore, S. A. (2004). Bringing science to wildlife tourism: The influence of managers' and scientists' perceptions. Journal of Ecotourism, 3, 1-19. https://doi. org/10.1080/14724040408668147

Rodger, K., Moore, S. A., \& Newsome, D. (2010). Wildlife tourism science and scientists: Barriers and opportunities. Society and Natural Resources, 23, 679-694. https://doi. org/10.1080/08941920802438600

Räikkönen, J., \& Grénman, M. (2017). The experience economy logic in the wellness tourism industry. In A. Correia, M. Kozak, J. Gnoth, \& A. Fyall (Eds.), Co-creation and well-being in tourism (pp. 3-18). Cham: Springer.

Räikkönen, J. \& Suni, X (forthcoming). Erityinen mielenkiinnonkohde matkailun motiivina: Esimerkkitapauksina tiede- ja metsästysmatkailu.

Scott, W., \& Gough, S. (2007). Universities and sustainable development: The necessity for barriers to change. Perspectives: Policy and Practice in Higher Education, 11, 107-115. https://doi. org/10.1080/13603100701613947

Sedlacek, S. (2013). The role of universities in fostering sustainable development at the regional level. Journal of Cleaner Production, 48, 74-84. https://doi.org/10.1016/j.jclepro.2013.01.029

Sellmann, D., \& Bogner, F. X. (2013). Climate change education: Quantitatively assessing the impact of a botanical garden as an informal learning environment. Environmental Education Research, 19, 415-429. https://doi.org/10.1080/13504622.2012.700696

Slocum, S., Kline, C., \& Holden, A. (Eds.) (2015). Scientific tourism: Researchers as travellers. Abingdon: Routledge.

Spenceley, A. (2008). Requirements for sustainable nature-based tourism in transfrontier conservation areas: A southern African Delphi consultation. Tourism Geographies, 10, 285-311. https://doi.org/10.1080/14616680802236295

Stilgoe, J., Lock, S. J., \& Wilsdon, J. (2014). Why should we promote public engagement with science? Public Understanding of Science, 23(1), 4-15. https://doi.org/10.1177/0963662513518154

Stone, M. J., \& Petrick, J. F. (2013). The educational benefits of travel experiences: A literature review. Journal of Travel Research, 52, 731-744. https://doi.org/10.1177\%2F0047287513500588 
Thiel, M., Penna-Díaz, M. A., Luna-Jorquera, G., Salas, S., Sellanes, J., \& Stotz, W. (2014). Citizen scientists and marine research: Volunteer participants, their contributions, and projection for the future. Oceanography and Marine Biology: An Annual Review, 52, 257-314. https://doi. org/10.1201/b17143-6

Thompson, R., \& Starzomski, B. M. (2007). What does biodiversity actually do? A review for managers and policy makers. Biodiversity and Conservation, 16, 1359-1378. https://doi.org/10.1007/ s10531-005-6232-9

TIES. (2015). What is ecotourism? Retrieved March, 11, 2019 from https://ecotourism.org/ what-is-ecotourism/

Vicente-Molina, M. A., Fernández-Sáinz, A., \& Izagirre-Olaizola, J. (2013). Environmental knowledge and other variables affecting pro-environmental behaviour: Comparison of university students from emerging and advanced countries. Journal of Cleaner Production, 61, 130-138. https://doi.org/10.1016/j.jclepro.2013.05.015

Vicente-Sáez, R., \& Martínez-Fuentes, C. (2018). Open Science now: A systematic literature review for an integrated definition. Journal of Business Research, 88, 428-436. https://doi. org/10.1016/j.jbusres.2017.12.043

Waas, T., Hugé, J., Verbruggen, A., \& Wright, T. (2011). Sustainable development: A bird's eye view. Sustainability, 3, 1637-1661. https://doi.org/10.3390/su3101637

Waas, T., Verbruggen, A., \& Wright, T. (2010). University research for sustainable development: Definition and characteristics explored. Journal of Cleaner Production, 18, 629-636. https://doi. org/10.1016/j.jclepro.2009.09.017

Wals, A. E. J. (2007). Social learning towards a sustainable world: Principles, perspectives, and praxis. Wageningen Academic Publishers.

Wals, A. E. J. (2014). Sustainability in higher education in the context of the UN DESD: A review of learning and institutionalization processes. Journal of Cleaner Production, 62, 8-15. https:// doi.org/10.1016/j.jclepro.2013.06.007

Wals, A. E. J., Brody, M., Dillon, J., \& Stevenson, R. B. (2014). Convergence between science and environmental education. Science, 344, 583-584. https://doi.org/10.1126/science.1250515

Wals, A. E. J., \& Jickling, B. (2002). "Sustainability" in higher education: From doublethink and newspeak to critical thinking and meaningful learning. International Journal of Sustainability in Higher Education, 3, 221-232. https://doi.org/10.1108/14676370210434688

Weaver, D. B. (2005). Comprehensive and minimalist dimensions of ecotourism. Annals of Tourism Research, 32, 439-455. https://doi.org/10.1016/j.annals.2004.08.003

Weissman, N. B. (2012). Sustainability \& liberal education: Partners by nature. Liberal Education, 98(4), 6-13.

West, P. (2008). Tourism as science and science as tourism. Current Anthropology, 49, 597-626. https://doi.org/10.1086/586737 
Wiek, A., Withycombe, L., \& Redman, C. L. (2011). Key competencies in sustainability: A reference framework for academic program development. Sustainability Science, 6, 203-218. https:// doi.org/10.1007/s11625-011-0132-6

Wright, T. (2004). The evolution of sustainability declarations in higher education. In P. Blaze Corcoran \& A. E. J. Wals (Eds.), Higher education and the challenge of sustainability (pp. 7-19). Dordrecht: Kluwer Academic Publishers.

Wu, Y.-C. J., \& Shen, J.-P. (2016). Higher education for sustainable development: A systematic review. International Journal of Sustainability in Higher Education, 17, 633-651. https://doi. org/10.1108/IJSHE-01-2015-0004

Xiao, H., \& Smith, S. L. (2007). The use of tourism knowledge: Research propositions. Annals of Tourism Research, 34, 310-331. https://doi.org/10.1016/j.annals.2006.09.001

Zelenika, I., Moreau, T., Lane, O., \& Zhao, J. (2018). Sustainability education in a botanical garden promotes environmental knowledge, attitudes and willingness to act. Environmental Education Research, 24, 1581-1596. https://doi.org/10.1080/13504622.2018.1492705 